\title{
The Practice Model of Innovation and Entrepreneurship Education in China's Colleges and Universities
}

\author{
Chen Jian \\ School of Finance, \\ Guangdong University of Foreign Studies \\ Guangzhou, China \\ 200711642@oamail.gdufs.edu.cn
}

\begin{abstract}
This paper attempts to sort out and summarizes the development model of innovation and entrepreneurship education in colleges and universities, and explores the development path of innovation and entrepreneurship education that are in line with our national conditions. From the perspective of original innovation content, this paper divides the practice model of innovation and entrepreneurship education into three types: innovation-driven, mode-driven and skill-driven, and also analyzes their respective characteristics and internal logic. In the end, the paper draws the conclusion that colleges and universities should choose a development model of innovation and entrepreneurship education that is suitable for school situations, and develop innovation and entrepreneurship education incrementally, establish classified dynamic evaluation system of innovation and entrepreneurship education, and construct a multi-level and multi-mode innovation and entrepreneurship training support system.
\end{abstract}

Keywords-Innovation and entrepreneurship education; Higher education; Development model; Original innovation

\section{INTRODUCTION}

In his 2015 government work report, Premier Li Keqiang put forward the call of "mass entrepreneurship and innovation" to speed up the implementation of the innovation driven strategy, and the development of innovative and entrepreneurial talents and innovation and entrepreneurship education in Colleges and universities were mentioned at an unprecedented important level. Clarifying the development mode of innovation and entrepreneurship education and the characteristics of various models will help us further clarify our thinking and speed up the training of innovative and entrepreneurial talents.
II. The Present Situation of The Practice Mode of INNOVATION AND ENTREPRENEURSHIP EDUCATION IN CHINA'S COLLEGES AND UNIVERSITIES

Since Tsinghua University set up entrepreneurship curriculum in 1998, based on the experience of foreign innovation and entrepreneurship education, and based on its own school running concept and the limitation of teachers' resources, we explored a distinctive development mode of entrepreneurship education. For example, the Tsinghua University "deep focus on education mode ",Renmin University of China" classroom development mode "," the implementation of Heilongjiang University "curriculum, practice, guarantee "as one of the integrated mode, Shanghai Jiao Tong University "full coverage and level of innovation and entrepreneurship education system", Wenzhou University "post entrepreneurship education mode" [1], Northeast Normal University" broad-spectrum "innovation and entrepreneurship education mode[2].

What are the characteristics and development trends of the existing innovation and entrepreneurship education mode in Colleges and universities? What is the practical mode of innovation and entrepreneurship education that suits the national conditions of our country? Chinese and foreign scholars have carried out a great deal of research on the above two problems and formed a rich achievement. According to its research perspective, the existing literature can be divided into three categories: one is the study of the innovation and entrepreneurship education practice mode from the perspective of the specific content, such as Chen Ruiying, Gu Zheng (2010) the model of entrepreneurship education in Colleges and universities is divided into entrepreneurial innovation of Japanese professional education mode, management mode and practice skills in the model, the entrepreneur entrepreneurial skills conservation mode[3]; Li Weiming (2013) proposed the Wenzhou University job mode of entrepreneurship education; Wang Zhanren (2010) put forward the" broad-spectrum "innovation and entrepreneurship education mode; Wang Xiaohong (2014) proposed the main mode of training team spirit of innovation and entrepreneurship education[4]; Song Shuang, Yang Jianquan (2016) puts forward the innovation and 
entrepreneurship mode of "three systems and one center" relying on theory teaching system optimization by the academic competition, practice teaching system and quality development system as well as "four levels and three types" and "combination of entrepreneurship and incubation" model which is full participated, hierarchical and gradual [5] .

The other is from the perspective of educational resource organization. For example, Mei Weihui put forward the focus mode of American entrepreneurship education, magnet mode, radiation mode; Liu Shugen etc. (2015) proposed fusion model, intermediary mode, external support mode based on the British university innovation and entrepreneurship education [6]; $\mathrm{Hu}$ Chao (2016) classified the mode of innovation and entrepreneurship education in China into three mode: independent college mode, school attachment mode, mode of multi-sectoral collaboration [7]. "Three is from the perspective of elements of innovation and innovation system and out of innovation and entrepreneurship education in Colleges and universities to look at. Referring to" university- enterprise government" three spiral model, they put forward the ecological network model[8], "organizational-cultureeducation" three-in-one model [9], "the curriculum system, the reform of personnel training, guided by the government, universities as the main undertakers, and enterprises as participants "service management model [10].

The eighteen party put forward the strategy of innovation driven development, which requires technological innovation, institutional innovation and business mode innovation. Technological innovation is the core and key. At present, the key to change the way of economic development is independent innovation. Therefore, the state has made great efforts to cultivate independent innovation ability and encourage the high content of original innovation. As one of the sources of the original innovation, the university needs to adapt to the reform of the innovative and entrepreneurial education model.

Based on the national strategy of innovation driven development, this paper will conduct the research to practice modes of innovation and entrepreneurship education in universities in China from perspective of elements of original innovation. And it will analyze the characteristics and mechanisms of different mode, and try to find out innovation and entrepreneurship education mode and development path suitable for the situation of Chinese.
III. THE ClassificATION AND CHARACTERISTICS OF THE PRACTICE MODEL OF INNOVATION AND ENTREPRENEURSHIP EDUCATION IN CHINA'S COLLEGES AND UNIVERSITIES: BASED ON THE PERSPECTIVE OF ORIGINAL INNOVATION

Premier Li Keqiang put forward the "public entrepreneurship, innovation" management of the national development strategy, with particular emphasis on cultivating original innovation consciousness. Original innovation refers to the unprecedented achievements of important scientific discoveries, technological inventions, and principles leading technology. Cultivating the original innovation that is most fundamental innovation is the focus of the national innovation driving strategy and the development direction of innovation and entrepreneurship education. According to the number of innovative elements, especially the amount of original innovation, innovation and entrepreneurship education modes in universities can be classified into three education models.

\section{A. Innovation-driven type}

Innovation-driven innovation and entrepreneurship education contains the most elements of the original innovation, which points that entrepreneurial behavior has significant features of original innovation and high-tech. It emphasizes the cultivation of original innovation consciousness and quality in the process of personnel training, taking science and technology innovation and entrepreneurship as the main content, integration of industry, education and research into practice, driving innovation and entrepreneurship training with original innovation. As a result, it makes great contribution to building national innovation system.

In innovation-driven innovation and entrepreneurship education, colleges and universities rely on their own original strong scientific research foundation (original accumulation) and a relatively strong tradition of innovation and entrepreneurship to implement an effective incentive mechanism to encourage innovation and entrepreneurship, and create a comprehensive platform and environment with a strong stimulus to students and teachers as well as innovative core figures to lead the team to collaborate on innovation and entrepreneurship activities, in order to cultivate innovative and entrepreneurship top talent in the field of basic sciences and high-tech innovation. The university with this mode is closely related to the national innovation driven strategy. It is an important part of the national innovation system. It is often supported by the national key construction funds such as the 985 plan and the 211 plan. Most of them belong to the key comprehensive university of the Ministry of education. Tsinghua University is the typical college of the model. 


\section{B. Model-driven type}

Model-driven innovation and entrepreneurship education contains few original innovations, and its entrepreneurial behavior points to the distinctive features of regional innovation or service innovation. Emphasis is put on the application of knowledge of innovation and entrepreneurship in the process of talent cultivation, and the innovation and Entrepreneurship in a certain application field as the main content of education. In practice, Emphasis is put on reorganization and innovation of teaching resources and organization, and application innovation and organizational innovation to drive the cultivation of innovative entrepreneurship. As a result, it contributes more to the construction of regional innovation and entrepreneurship system.

In the model-driven innovation and entrepreneurship education, colleges and universities respond to the needs of training innovative and pioneering professionals in local innovative and entrepreneurial activities and professional applications, and take the initiative to reform and innovate their own teaching philosophy, educational resources, organizational modes and operating mechanisms to cultivate innovative entrepreneurs who can adapt to a certain area or specialty field. Most of the universities adopting this mode are provincial local colleges, ordinary undergraduate colleges and liberal arts colleges. Their basic scientific research strength is relatively general, but they are closely linked with the local innovation and entrepreneurship industry activities and practice circles, and they are the key points of regional innovation System of the important forces. Heilongjiang University is a typical university.

\section{Skill-driven type}

Skill-driven innovation and entrepreneurship education contains the least elements of the original innovation, which points that the entrepreneurial behavior has the characteristics of survival entrepreneurship, emphasizes the acquisition and entrepreneurship practice of entrepreneurial skills in the process of talent cultivation, and combines closely with post education. Practice training and school enterprise cooperation is mostly adopted, and the development of innovation and entrepreneurship education in Colleges and universities is driven by skills training and expansion of employment.

In skill-driven innovation and entrepreneurship education, colleges and universities combine the types of job talents in shortage and requirements of high-quality innovative talents, innovate teaching concept of personnel training in job talents, as well as post education and educational carrier, in order to cultivate high-quality innovative talents of social scarce jobs. The majority of colleges and universities adopting this model are higher vocational colleges and universities. Students have strong ability to practice, urgently get hired through acquiring innovative skills. In this model, large number of people are engaged in innovation and entrepreneurship on a wide range of fields. They are the basic strength of the regional innovation system and the key to expand employment. This type of model is often seen in higher vocational colleges. Changzhou College of Information Technology and other vocational colleges are the typical colleges and universities.

\section{THE INTERnAl Logic AND CONNECTION IN THE MODE OF INNOVATION AND ENTREPRENEURSHIP EDUCATION}

An important factor affecting the original innovation is the primitive accumulation. The primitive accumulation is the premise of the original innovation, and it is an essential link. The primitive accumulation includes five aspects: scientific research foundation, talent, academic tradition, knowledge and individual experience. When the primitive accumulation reaches a certain level, under the joint efforts of innovative core figures, strong innovation atmosphere, scientific incentive mechanism, great interest in scientific research and teamwork, it is possible to produce original innovation.

It can be seen from the above analysis that the essential difference between the three innovation-driven, model-driven and skill-driven education modes is the original element of innovation. Among them, the innovation-driven innovation and entrepreneurship education has the most original innovation elements, which is the education model with the most primary innovative output, followed by the model-driven and skilldriven. There are inherent transformation mechanisms in the three modes of education. From the perspective of primitive accumulation, although there are fewer original innovation elements of pattern-driven and skill-driven, there is also a possibility of shifting to an innovation-driven pattern after a period of primitive accumulation.

\section{THE REFORM OF THE MODE OF INNOVATION AND ENTREPRENEURSHIP EDUCATION IN CHINA AND THE POLICY SUGGESTIONS}

In the practice of innovation and entrepreneurship education, most of our colleges and universities formed a unique innovation and entrepreneurship education system and education model according to local conditions, which effectively promoted the development of innovation and entrepreneurship education and the cultivation of innovative entrepreneurship talents. However, due to the constraints of education concept and education system and the urgency of accomplishing superior tasks, some universities and regions have the practical mistakes of blind pursuit of innovationdriven mode, assessment and evaluation across the board, and lack of multi-level and multi-mode innovative personnel training system and support system. There is an urgent need for reform and innovation. 
A. Independent selection of the innovation and entrepreneurship education development model suitable for the school situation and the gradual development of innovation and Entrepreneurship Education

Innovation-driven, model-driven, and skills-driven innovation and entrepreneurship education play a very important role in the process of innovation and personnel training. They are important components of a multi-level national innovation system and should not be neglected. the hardware and software required by The three types of innovation and entrepreneurship education are different. Moreover, there are also significant differences in the socioeconomic environment in which various models are adapted. All colleges and universities should make clear their own historical mission, select appropriate innovation and entrepreneurship education mode and put into practice according to their own development orientation and historical conditions, integrate innovative and entrepreneurship education with comprehensive reform of colleges and universities, and promote them progressively. It will help to promote the cultivation of innovative entrepreneurship talents.

\section{B. Establish a dynamic and classified evaluation system for innovation and Entrepreneurship Education}

When formulating the evaluation indicators for innovation and entrepreneurship education in colleges and universities, all education authorities should recognize the diversification of education subjects, take full account of the characteristics of the stages and institutional differences, allow colleges and universities to carry out innovation and entrepreneurship education in a gradual and orderly manner, and carry out classified, dynamic assessment and evaluation. It will help to develop innovation and entrepreneurship education in all colleges and universities healthily. According to the different stage of education development, colleges and universities with better foundations for innovation and entrepreneurship education should focus on the integrated utilization of resources both inside and outside and the research and practice of educational theories. For colleges and universities with weak foundations, the emphasis should be on popularizing the concept of innovation and entrepreneurship education and on obtaining relevant social resources. For colleges and universities in different regions or economically developed coastal provinces with private economy, the evaluation focuses on the cultivation of students' entrepreneurial ability and entrepreneurship practice, and whether or not they have established a benign mechanism to cultivate the modern service industry. For high-tech industry clusters, universities with rich resources in Beijing, Tianjin and Shenzhen, the evaluation focuses on the cultivation of students' innovative spirit and entrepreneurial consciousness, and whether a benign mechanism for cultivating technological entrepreneurship is established [11].

\section{Establish a multi-level, multi-mode innovation and entrepreneurship training system}

The three major types of innovation and entrepreneurship education, which are innovation-driven, mode-driven, and skills-driven, are important components of China's innovation and entrepreneurship education system. The state should establish a multi-level and multi-mode innovation and entrepreneurship training support system to speed up development of innovation and entrepreneurship education. Universities with different innovation and entrepreneurship education modes have different ways to innovate and risk. They have different contributions to the innovation system. The state and local governments should classify and give priority to support. For innovation-driven colleges and universities, their original innovation is large, the output period of original innovation is long, the capital investment required is large, and the output uncertainty is large. Therefore, the state should provide financial supports that are full coverage, longterm and large-scale. For model-driven colleges and universities, the number of them is large. The state should provide financial support to typical universities with regional or industry characteristics. At the same time, the state pays attention to the establishment of incentive mechanism and cooperation between model-driven colleges and universities, professional associations and business groups such as industry associations, government departments, think tanks, etc, as well as putting the innovation and entrepreneurship education in colleges and universities, professional education and personnel training into in-depth integration of the reform process. For skill-driven colleges and universities, the state should give priority to the training of professions urgently needed by the society and establish an incentive mechanism to encourage the cooperation between schools and enterprises so as to fully mobilize the enthusiasm and wisdom of enterprises in innovating and undertaking education.

\section{CONCLUSION}

This study found that according to the amount of original innovation, it can be divided into innovation-driven, modedriven, and skill-driven. The essential difference between these three modes is the difference in the content of original innovative elements. Model-driven and skill-driven universities can transform themselves into an innovation-driven one through primitive accumulation, which increase original innovation content. All three models are an important part of the innovation and entrepreneurship education system in colleges and universities. All colleges and universities should choose the model of innovation and entrepreneurship education suitable for school conditions and develop innovative and pioneering education step by step. Education authorities in all localities should set up a dynamic evaluation system of innovation and entrepreneurship education and a support system for multi-level and multi-mode innovation and entrepreneurship training. 


\section{ACKNOWLEDGMENT}

We are grateful to the Guangdong Province 2015 Education Reform General Project " construction of college students business curriculum under the background of complete credit system- taking business design as an example" , Guangdong Province Philosophy and Social Sciences 12th Five-Year Planning Project discipline co-construction project (GD15XYJ06), and Guangdong Province 2016 Graduate Education Innovation Project "Research and practice on training mode of economics and management degree graduate based on innovation and entrepreneurship-oriented methods" for funding this research.

\section{REFERENCES}

[1] Li Weiming, Li Chunyan, Du Xiaohua. "Ten years of entrepreneurship education in chinese universities: evolution, issues and system construction,” Educational Research, vol.6,2013,pp 42-51. (In Chinese)

[2] Wang Zhanren. "Analysis on 'Broad spectrum' innovation and entrepreneurship education system," Education Development Research .vol.6,2010,pp 54-58. (In Chinese)

[3] Chen Ruiying, Gu Zheng. "Entrepreneurship education in Japanese universities in the new century: status and issues," Higher Engineering Education Research.vol.2, 2010,pp22-30.(In Chinese)

[4] Wang Xiaohong. " Research on innovation and entrepreneurship education model for college students - From the perspective of team spirit cultivation," Hubei Social Sciences. vol.10, pp 187-189. (In Chinese)

[5] Song Shuang, Yang Jianquan. "Exploration and practice of innovation and entrepreneurship education by discipline competition," Laboratory research and exploration.vol.11,2016, pp193-195. (In Chinese)

[6] Liu Shugen, Cheng Xiaoliang, Cao Junxing. "Characteristics and enlightenment of entrepreneurship education in British universities," China University of Education.vol.3, 2015, pp31,85-88. (In Chinese)

[7] $\mathrm{Hu}$ Chao, Chang Qinghui. "The construction of a new model of entrepreneurship education in colleges and universities - Based on the comparison of entrepreneurship education organizations in China and the United States," Higher Education Institution Management. vol.1, 2016, pp80-85. (In Chinese)

[8] Ma Yongbin, Bai Zhe. "Research and Exploration on Practice Models of Innovation and Entrepreneurship Education in Universities," Journal of Education Research of Tsinghua University.vol.6,2015, pp 99-103. (In Chinese)

[9] Liu Yanjun. "Exploration of innovation and entrepreneurship education in the context of comprehensive higher education reform," Science and Technology in Chinese Universities.vol.9,2015,pp 82-85. (In Chinese)

[10] Cao Jianhui, Zhou Hebing, Luo Yifan. "Research and exploration on modes of innovation and entrepreneurship education in universities," Journal of Laboratory Research and Exploration.vol.8,2010, pp195-198. (In Chinese)

[11] Zhang Yan. "Differentiation and strategic thinking of innovation and entrepreneurship education in colleges and universities," China Higher Education, vol.23,2010,pp45-46. (In Chinese) 